\title{
Materials and Structures Research for Gas Turbine Applications Within the NASA Subsonic Fixed Wing Project
}

Janet Hurst

Glenn Research Center, Cleveland, Ohio 


\section{NASA STI Program . . . in Profile}

Since its founding, NASA has been dedicated to the advancement of aeronautics and space science. The NASA Scientific and Technical Information (STI) program plays a key part in helping NASA maintain this important role.

The NASA STI Program operates under the auspices of the Agency Chief Information Officer. It collects, organizes, provides for archiving, and disseminates NASA's STI. The NASA STI program provides access to the NASA Aeronautics and Space Database and its public interface, the NASA Technical Reports Server, thus providing one of the largest collections of aeronautical and space science STI in the world. Results are published in both non-NASA channels and by NASA in the NASA STI Report Series, which includes the following report types:

- TECHNICAL PUBLICATION. Reports of completed research or a major significant phase of research that present the results of NASA programs and include extensive data or theoretical analysis. Includes compilations of significant scientific and technical data and information deemed to be of continuing reference value. NASA counterpart of peer-reviewed formal professional papers but has less stringent limitations on manuscript length and extent of graphic presentations.

- TECHNICAL MEMORANDUM. Scientific and technical findings that are preliminary or of specialized interest, e.g., quick release reports, working papers, and bibliographies that contain minimal annotation. Does not contain extensive analysis.

- CONTRACTOR REPORT. Scientific and technical findings by NASA-sponsored contractors and grantees.
- CONFERENCE PUBLICATION. Collected papers from scientific and technical conferences, symposia, seminars, or other meetings sponsored or cosponsored by NASA.

- SPECIAL PUBLICATION. Scientific, technical, or historical information from NASA programs, projects, and missions, often concerned with subjects having substantial public interest.

- TECHNICAL TRANSLATION. Englishlanguage translations of foreign scientific and technical material pertinent to NASA's mission.

Specialized services also include creating custom thesauri, building customized databases, organizing and publishing research results.

For more information about the NASA STI program, see the following:

- Access the NASA STI program home page at http://www.sti.nasa.gov

- E-mail your question via the Internet to help@ sti.nasa.gov

- Fax your question to the NASA STI Help Desk at $443-757-5803$

- Telephone the NASA STI Help Desk at 443-757-5802

- Write to: NASA Center for AeroSpace Information (CASI) 7115 Standard Drive Hanover, MD 21076-1320 


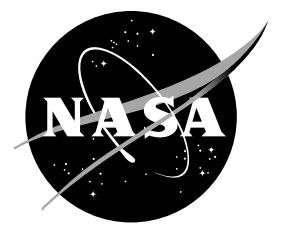

\section{Materials and Structures Research for Gas Turbine Applications Within the NASA Subsonic Fixed Wing Project}

Janet Hurst

Glenn Research Center, Cleveland, Ohio

Prepared for the

Turbo Expo 2010

sponsored by the American Society of Mechanical Engineers (ASME)

Glasgow, Scotland, United Kingdom, June 14-18, 2010

National Aeronautics and

Space Administration

Glenn Research Center

Cleveland, Ohio 44135 


\section{Acknowledgments}

I would like to acknowledge the numerous contributors to this overview-Dr. Michael Nathal, Dr. Rebecca MacKay, Dr. Ron Noebe, Dr. Margaret Proctor, Dr. Cheryl Bowman, Dr. Jeff Eldridge, Dr. Robert Miller, Dr. Dongming Zhu, Dr. George Stefko, Dr. Kirsten Duffy, Dr. James Min, Dr. Ben Choi, Dr. Gerald Brown, Dr. Tom Cable, and others.

This report is a formal draft or working paper, intended to solicit comments and ideas from a technical peer group.

This report contains preliminary findings, subject to revision as analysis proceeds.

Level of Review: This material has been technically reviewed by technical management.

Available from

NASA Center for Aerospace Information 7115 Standard Drive

Hanover, MD 21076-1320
National Technical Information Service 5301 Shawnee Road Alexandria, VA 22312

Available electronically at http://www.sti.nasa.gov 


\title{
Materials and Structures Research for Gas Turbine Applications Within the NASA Subsonic Fixed Wing Project
}

\author{
Janet Hurst \\ National Aeronautics and Space Administration \\ Glenn Research Center \\ Cleveland, Ohio 44135
}

\begin{abstract}
In an era of both declining NASA budgets and demanding space goals, the NASA Aeronautics Research Mission Directorate has elected to address foundational research problems for aeronautics. To this end, the Subsonic Fixed Wing (SFW) Project, within the Fundamental Aeronautics Program, has selected challenging goals which anticipate an increasing emphasis on aviation's impact upon the global issue of environmental responsibility. These SFW project goals are greatly reduced noise, reduced emissions and reduced fuel consumption. Specific goals, selected by a combination of systems analysis, experience and industry input, are generational in approach, addressing 25 to 30 years of technology development. Successful implementation of these demanding goals will require development of new materials and structural approaches within gas turbine propulsion technology.

The Materials and Structures discipline, within the SFW project, comprise cross-cutting technologies ranging from basic investigations to component validation in laboratory environments. Material advances are teamed with innovative designs in a multidisciplinary approach with the resulting technology advances directed to promote the goals of reduced noise and emissions along with improved performance. For propulsion needs, these technologies have been grouped into three basic categories. These are 1) improved hot section materials for hotter engines with minimal cooling requirements to promote reduced $\mathrm{NO}_{\mathrm{x}}$ and fuel burn. Among the technologies of interest have been new alloy compositions and coatings which are demonstrating improved capabilities for this purpose. Also of interest for propulsion applications are 2) lightweight and multifunctional systems which will allow reduced fuel burn via weight reduction in the engine and its surrounding structure. An example of this technology is High Temperature Shape Memory Alloys (HTSMA) for actuation applications requiring large displacements and low frequencies such as chevrons and variable area nozzles for high bypass ratio engines. The final area under investigation is 3) More Electric aircraft, which at this time is focused primarily on Turboelectric technology as a revolutionary approach to the entire SFW design space. Major challenges to be addressed in this field are improved cryocoolers and superconducting materials.
\end{abstract}

A brief overview is presented of the current materials and structures research focused upon propulsion applications within NASA Subsonic Fixed Wing Project. As such, it does not comprise the entirety of Materials and Structure research for gas turbine engines at NASA. Several other projects also include research of this type to address their specific project goals.

\section{Introduction}

The objective of the Subsonic Fixed Wing Project (SFW), one of four flight regime based projects within the NASA Fundamental Aeronautics Program, is to conduct discipline based foundational research to address environmental challenges and improve the performance of subsonic aircraft (Ref. 1). The aggressive goals of the SFW project are shown in Figure 1 and define a design space with large reductions in noise, NOx, fuel burn and reduced runway length. A generational approach is used by the SFW project with current generation aircraft referred to as " $\mathrm{N}$ " and so forth from nearterm concepts or $\mathrm{N}+1$, mid-term ideas designated as $\mathrm{N}+2$, to the basic research ideas which will enable new $\mathrm{N}+3$ aircraft concepts in 30 years or more. The achievement of these goals requires a multidisciplinary effort to investigate new materials, structural concepts and technologies. Within the Materials and Structures discipline are cross-cutting technologies with overlapping applications within each of the four flight regime based FA projects. Technologies of interest are divided among the four projects, with considerable cooperation existing between those projects at the discipline level. For incorporation in the SFW portfolio, three criterions must be addressed. The first being whether the technology enables a significant, achievable impact on the goals of SFW. The second one is whether the technology fits best within SFW or would be better aligned with the goals of another project. The third criterion is whether there are sufficient resources available to make reasonable progress. Technologies from very basic fundamental research to nearer term concepts are included. Additionally, vigorous supplementation of in-house capabilities is accomplished via periodic NASA Research Announcements (NRA). Four NRA rounds have been pursued thus far, one each year of the SFW project with significant university involvement. Additionally, the Small Business Innovation Research program (SBIR) has usefully augmented the research portfolio.

The critical materials and structures technology needs for subsonic flight regime applications have been identified as 1) improved hot section materials, 2) improved lightweight structures which employ improved and/or multifunctional materials with an integrated design solution and 3) more electric aircraft to meet future consumer and industry needs. 


\begin{tabular}{|l|c|l|l|}
\hline $\begin{array}{l}\text { CORNERS OF } \\
\text { THE TRADE } \\
\text { SPACE }\end{array}$ & $\begin{array}{l}\text { N+1 (2015) } \\
\text { GENERATION } \\
\text { Conventional } \\
\text { Configurations } \\
\text { (Tube and Wing) }\end{array}$ & $\begin{array}{l}\text { N+2 (2020) } \\
\text { GENERATION } \\
\text { Unconventional } \\
\text { Configurations } \\
\text { (Hybrid Wing) }\end{array}$ & $\begin{array}{l}\text { N+3 (2030) } \\
\text { GENERATION } \\
\text { Advanced Aircraft } \\
\text { Concepts relative to } \\
\text { user-defined reference }\end{array}$ \\
\hline $\begin{array}{l}\text { Noise } \\
\text { (cum below Stage4) }\end{array}$ & $-32 \mathrm{~dB}$ & $-42 \mathrm{~dB}$ & $-71 \mathrm{~dB}$ \\
$\begin{array}{l}\text { LTO NOx } \\
\text { Emissions } \\
\text { (below CAEP/6) }\end{array}$ & $-60 \%$ & $-75 \%$ & better than $-75 \%$ \\
$\begin{array}{l}\text { Performance: } \\
\text { Aircraft Fuel Burn }\end{array}$ & $-33 \%$ & $-40 \%$ & better than -70\% \\
Performance: & $-33 \%$ & $-50 \%$ & $\begin{array}{l}\text { exploit } \\
\text { Field Length }\end{array}$
\end{tabular}

Figure 1.-Subsonics Fixed Wing Project (SFW) System Level Metrics (Courtesy Ruben Delrosario, Principal Investigator).

\section{Nomenclature}

$\begin{array}{ll}\text { AFRL } & \text { Air Force Research Laboratory } \\ \text { CMC } & \text { Ceramic Matrix Composites } \\ \text { EBC } & \text { Environmental Barrier Coating } \\ \text { ERA } & \text { Environmentally Responsible Aviation Project } \\ \text { FA } & \text { Fundamental Aeronautics } \\ \text { HTSMA } & \text { High Temperature Shape Memory Alloys } \\ \text { IPHTET } & \text { Integrated High Performance Turbine Engine } \\ & \text { Technology } \\ \text { LDS } & \text { Low Density Superalloy } \\ \text { NASA } & \text { National Aeronautics and Space Administration } \\ \text { GRC } & \text { NASA Glenn Research Center } \\ \text { NOx } & \text { Nitrogen and oxygen containing gases, very } \\ & \text { reactive } \\ \text { NRA } & \text { NASA Research Announcement } \\ \text { OPR } & \text { Overall Pressure Ratio } \\ \text { PM } & \text { Powder Metallurgy } \\ \text { TBC } & \text { Thermal Barrier Coating } \\ \text { SAA } & \text { Space Act Agreement } \\ \text { SBIR } & \text { Small Business Innovation Research } \\ \text { SFC } & \text { Specific Fuel Consumption } \\ \text { SFW } & \text { Subsonic Fixed Wing Project within the NASA } \\ & \text { Fundamental Aeronautics Program } \\ \text { SOFC } & \text { Solid Oxide Fuel Cell } \\ \text { T } & \text { Turbine Inlet Temperature } \\ & \end{array}$

\section{Hot Section Materials Research and Design}

Historically there has been a clear trend of increasingly higher operating temperatures within commercial class engines (Ref. 2). This trend is likely to continue with modern engine designs incorporating higher overall pressure ratios (OPR) and reduced film cooling and so driving the need for hot section materials to higher capabilities to provide both improved specific fuel consumption (SFC) and reduced NOx emissions To achieve these dual goals, new materials are needed as well as innovative designs. Improvements to hot section performance are being addressed by each of the FA programs. Additionally, the new Environmentally Responsible Aircraft project (ERA) is targeting improved NOx engines. At this time SFW is addressing several technologies for improved hot section performance these range potentially near term applications to basic research. Some of these to be discussed here include turbine seals, high temperature alloys and coatings, advanced hybrid disk concepts, multifunctional diagnostic coatings and high temperature nanotubes. Ceramic matrix composites (CMC) are also clearly of interest for advanced hot section components (Ref. 3), however CMC technology is adequately addressed by the other NASA projects flight regime based projects.

\section{High Temperature Seals}

Advanced gas turbine engine seals represent an opportunity to provide a significant reduction in specific fuel consumption (sfc) relative to current state-of-the-art (SOA) labyrinth seals. This reduced fuel burn is applicable across $\mathrm{N}, \mathrm{N}+1$, and $\mathrm{N}+2$ aircraft platforms, previously shown in Figure 1 . The commonly used labyrinth seals require clearance to avoid rubbing contact. Clearance must account for a range of engine conditions with centrifugal growth of the rotor, geometry changes due to thermal expansion, and dynamic shaft motion all occurring in response to mission profile. Abradable materials can be used to reduce this clearance, but once they are abraded, the gap remains. It has been shown that contacting brush or finger seals can result in half the leakage rate of conventional labyrinth seals (Refs. 4 to 7). Also studies by engine companies (Refs. 8 and 9) have shown that a 50 percent reduction in leakage will yield a 2 to 3 percent reduction in sfc. But a major drawback of these advanced seals is that shorter life results from rubbing wear of the contacting seal. SFW researchers are evaluating non-contacting compliant seals such as non-contacting brush/finger seals. These non-contacting finger seals holds promise to achieve low leakage rates and long life capability in subsonic gas turbine engines. A GRC designed non-contacting brush/finger turbine seal (Ref. 10) is shown in Figure 2. Verification and refinement of design methodology using experimental data and analysis is on-going with testing up to $800{ }^{\circ} \mathrm{C}$ and pressures up to $1.7 \mathrm{MPa}$ differential (250 psid). The goal of the current effort is to both validate design and analysis methodology, and to demonstrate leakage that is no more than 50 percent of SOA labyrinth seals and twice the life of contacting brush or finger seals at subsonic engine conditions. This work is conducted in the GRC High Temperature, High Speed Turbine Seal Test Facility, seen in Figure 3. Details regarding this facility have been reported elsewhere (Ref. 11). 


\section{Advanced High Temperature Alloys}

Metallurgurical engineers continue to make great improvements to alloy compositions and processing as engine temperature needs have increased. While there is undoubtedly a limit to the ultimate temperature which can be achieved with alloys, increases in upper use temperatures continue. Some applications, such as rotating components, are likely to require metal parts for the foreseeable future. Advanced alloy development continues to be a priority for the SFW project.

Within SFW, the alloy design space is characterized and optimized for cyclic oxidation, creep resistance, hot salt corrosion and microstructural stability. A series of nickelbased superalloys is under investigation for airfoil applications. The baseline composition in this series, known as LDS for low density superalloy, has been reported elsewhere (Refs. 12 and 13). These compositions possess excellent creep resistance and at the same time offer densities lower by 5 to 10 percent than the current generation of alloys. Figure 4 (Ref. 13) is a Larsen-Miller plot which illustrates the improved creep behavior of the baseline alloy (LDS,) as well as a further optimized composition, relative to state-of-the-art superalloys. These improvements have resulted in an additional $19{ }^{\circ} \mathrm{C}\left(35^{\circ} \mathrm{F}\right)$ increase in temperature capability and a $56{ }^{\circ} \mathrm{C}\left(100{ }^{\circ} \mathrm{F}\right)$ increase over commercial blade alloys. Efforts to transfer this technology to industry are underway through a NASA Space Act Agreement (SAA) with Honeywell Corporation.

\section{Advanced Hybrid Disk Concepts}

Improved turbine disks are another critical technology to enable higher temperature engine operation. Design considerations push for turbine inlet temperatures, $\mathrm{T}_{3}$, of $760{ }^{\circ} \mathrm{C}\left(1400^{\circ} \mathrm{F}\right)$ to $816^{\circ} \mathrm{C}\left(1500^{\circ} \mathrm{F}\right)$. While high temperature $\mathrm{CMCs}$ are being considered for other engine components, the high damage tolerance required by the turbine disk will likely negate the use of intermetallics or CMCs, at least for many years. Yet use of even advanced $2^{\text {nd }}$ and $3^{\text {rd }}$ generation powder metallurgy metals such as Rene 88 (Ref. 14) and ME3 (Ref. 15), confine $\mathrm{T}_{3}$ to no more than $1300^{\circ} \mathrm{F}$ due to creep and corrosion limitations. The need for higher use temperatures has prompted efforts to develop dual alloy concepts comprised of a powder metallurgy (PM) disk bonded to a single crystal superalloy rim, shown in Figure 5. By placing the joint between the two metals such that the PM alloy remains at no more than $704{ }^{\circ} \mathrm{C}\left(1300{ }^{\circ} \mathrm{F}\right)$, the single crystal rim alloy may operate to $760{ }^{\circ} \mathrm{C}\left(1400{ }^{\circ} \mathrm{F}\right)$ or more. The improved LDS single crystal alloy compositions developed for blades are candidates for this application as well.

Significant advances have been made in understanding the ultimate temperature capability of $3^{\text {rd }}$ generation powder metallurgy (PM) disk alloys. Also single crystal alloys with the necessary creep resistance have been identified, an example is shown in Figure 6. Additional work is on-going to

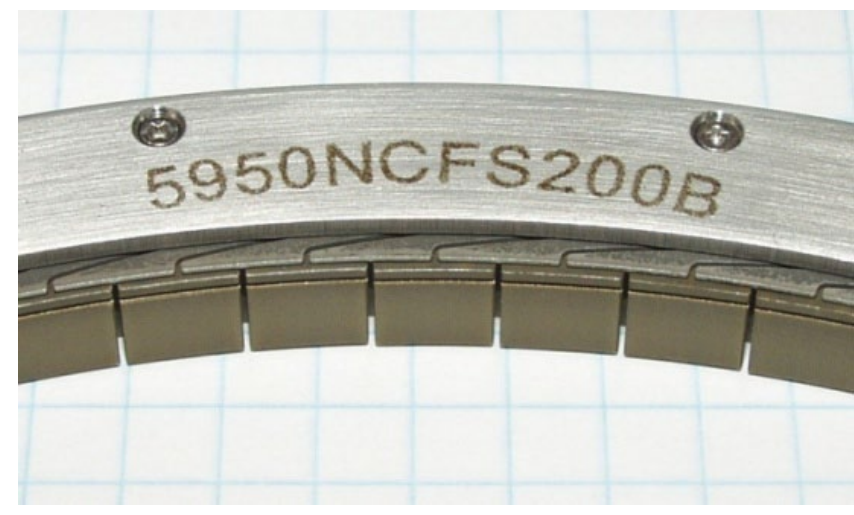

Figure 2.-GRC non-contacting brush/finger turbine seal (Ref. 10).

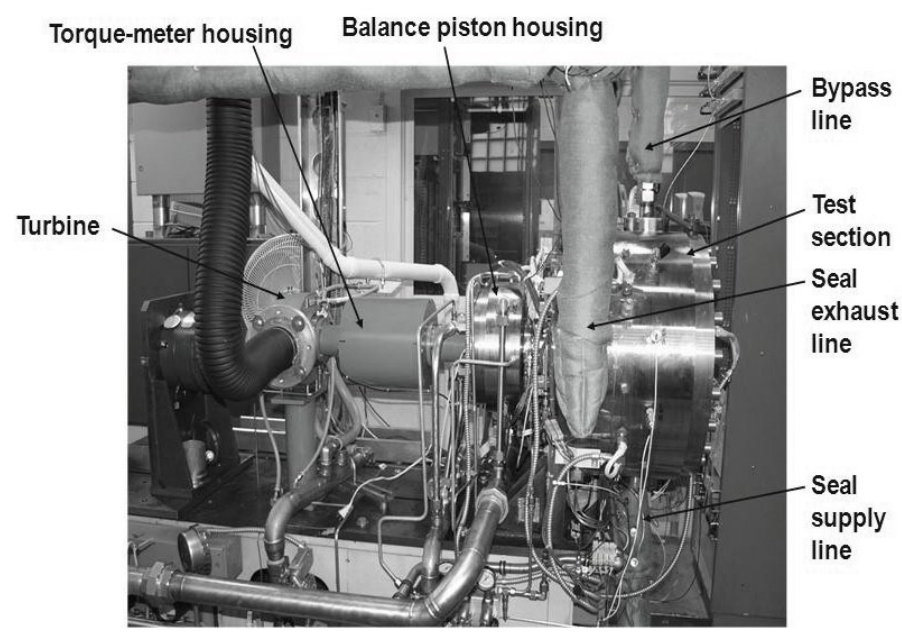

Figure 3.-GRC High Temperature, High Speed Turbine Seal Test Facility (Ref. 11).

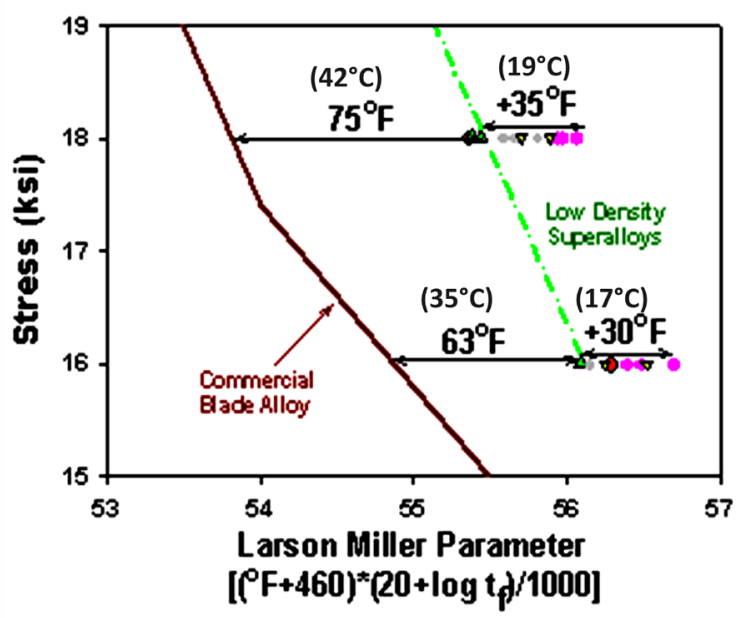

Figure 4.-Larsen-Miller plot of creep behavior of improved creep of SFW Developed alloys compared to commercial blade alloys (Ref. 13). 


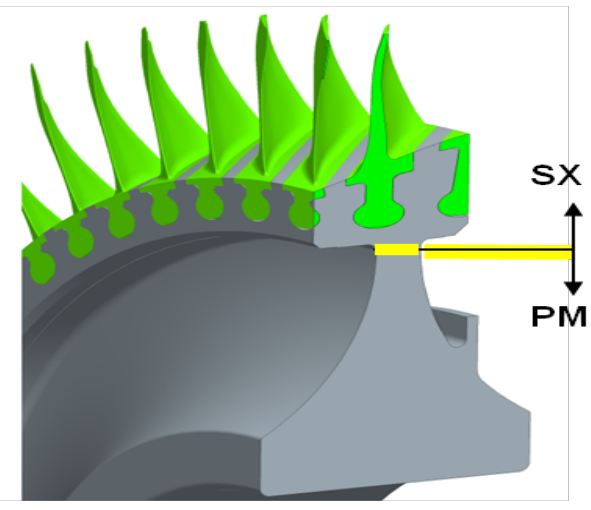

Figure 5.-Schematic of a hybrid disk section. (Courtesy of Michael Nathal, GRC.)

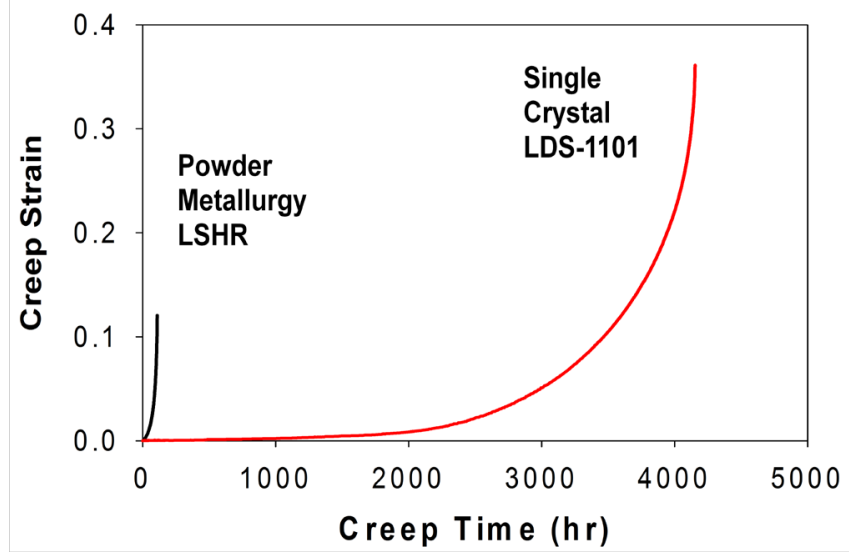

Figure 6._LDS alloys have creep resistance required for $816^{\circ} \mathrm{C}\left(1500^{\circ} \mathrm{F}\right)$ turbine disk rim temperatures (Ref 13).
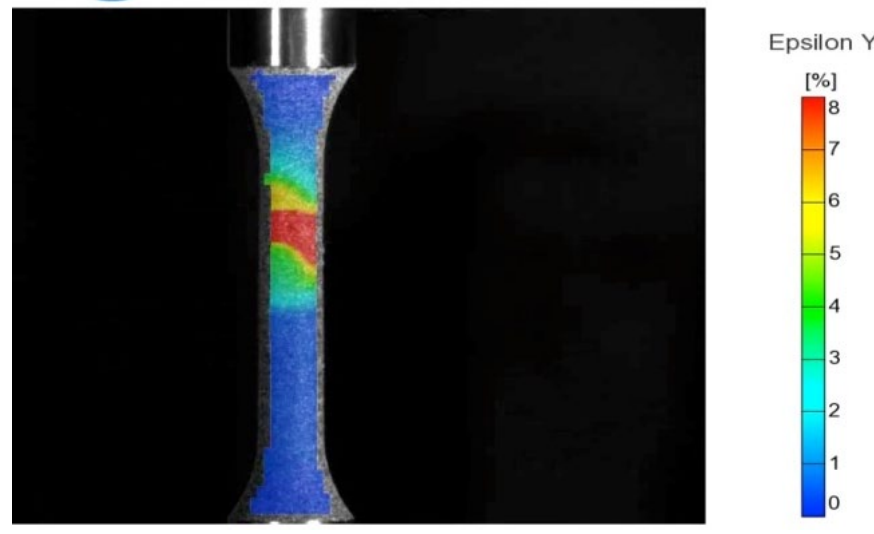

Figure 7.-Three-dimensional strain mapping of a PM/SX joint tensile specimen showing most of the deformation occurs in the single crystal region (Ref. 13). understand long term corrosion and oxidation behavior of this alloy family. Compositions must be optimized for a balance of properties within the alloy/property behavior maps. Also, promising brazing schemes and compositions for the $\mathrm{PM} /$ single crystal joint have been identified. Understanding the properties of this joined region will be critical to predict behavior of a component. By utilization of 3-D strain mapping during tensile testing, it has been shown that most of the deformation occurred within the single crystal, shown in Figure 7 (Ref. 13). Currently, an optimized high temperature coating scheme is being developed for this alloy/application system. Potentially a hybrid disk with CMCs may be considered, although thermal expansion mismatch would cause considerable stress at the joint.

The hybrid disk concept has been pursued in the past by DOD programs such as IHPET with NASA involvement. SFW GRC researchers are collaborating with AFRL to further the hybrid disk concept to enable to achieve a 100 to $200{ }^{\circ} \mathrm{F}$ increase in $T_{3}$ temperature. This effort relies on synergy between the advanced alloy work done within NASA's SFW, Supersonics and Aging Aircraft projects.

\section{High Temperature Coatings}

To further improve high temperature performance of stateof-the-art alloys, thermal barrier coatings must be developed in tandem with those alloys to optimize specifically targeted applications. Within SFW, coatings are actively under development are for the advanced superalloy compositions discussed previously for both blades and disks. As advanced engine designs push materials to increased temperatures, these coatings become critically important. An additionally pervasive issue for coating technology has been the potential premature loss of coating through spallation or erosion. Evaluation of the condition of the coatings is done by inspection of the part, often a difficult and expensive procedure. An innovative solution to this problem may be the application of luminescent coatings, described below, which provide both thermal protection and diagnostic health monitoring of the coating system. An additional multifunctional coating scheme also pursued within SFW has been thermal barrier coatings which also provide vibration damping to engine component.

\section{Delamination and Temperature Sensing Luminescence-Based Diagnostics for TBCs}

Thermal barrier coatings (TBCs) have been used to provide thermal protection for many turbine engine components. However, TBCs fail through spallation, leading to conditions which may damage engine performance or safety. Inspection of the TBC coating with nondestructive diagnostic tools could assess the progression of cracks within the coating (Refs. 16 to 18). This crack progression causes spallation which will lead to eventual TBC failure, as shown in Figure 8. Non-contacting 
temperature measurement of the substrate would also be useful, as then prediction of when the thermal function of the TBC was no longer effective would be possible. By careful doping of the TBC with luminescent sublayers, it has been found that crack progression can be monitored from an early stage, by near-infrared and upconversion luminescence imaging, before delamination can be detected visually, shown in Figure 9. Detection is possible because the buried delamination cracks are highly reflective and cause a relative increase in luminescent emission from delaminated areas. Prior to this near-infrared and upconversion luminescence imaging, the SOA techniques all had drawbacks which made implementation in an engine unlikely. Eddy current (Ref. 19) and impedance measurements (Refs. 20 and 21) are unsuitable for use in an engine, while techniques using optical probes had limitations in depth probing (Refs. 22 and 23). Pyrometry (Ref. 24) also suffered from uncertainty as emissivity measurements change with time at temperature. Luminescent subcoatings can also be used to monitor substrate temperature or surface temperature, depending on the location of the dopant (Ref. 25). It is important note that TBC life has not been affected by incorporation of luminecensing dopants (Ref. 26). Additionally, the incorporation of the dopants does not require difficult or cumbersome processing techniques. Dopants may be incorporated into commonly used coating deposition techniques such as plasma spraying (Ref. 26). Techniques such as this will be needed as engine operating temperatures are pushed to higher operating temperatures to monitor the condition of protective coatings. Plans are in place to demonstrate this technology in an engine test.

\section{Damping Coatings}

Another multifunctional capability of TBCs is the potential to damp vibrational stress within hot section components while also providing oxidation and erosion resistance. This coating scheme would enable thinner blades, or other component, while also reducing high cycle fatigue damage. A unique high temperature, high frequency, high force test capability was developed and demonstrated (Ref. 27), capable of testing at temperature up to $1230{ }^{\circ} \mathrm{C}$, shown in Figure 10. Metallic, ceramic and cermet coatings have been applied by both air plasma spraying and high velocity oxy-fuel (HVOF). An example of the initial results is shown in Figure 11. Up to a fourfold improvement in damping at $800{ }^{\circ} \mathrm{C}$ was found among the investigated coatings (Ref. 27).

\section{High Temperature Nanotubes}

In partnership with the Supersonics project, high temperature nanotubes are investigated for applications which are too harsh for carbon nanotubes (CNT). CNT are limited to approximately $500{ }^{\circ} \mathrm{C}$ in air while Boron Nitride Nanotubes (BNNT) and Silicon Carbide nanotubes (SiCNT) are stable to over $1000{ }^{\circ} \mathrm{C}$, as shown in Figures 12(a) (BNNT), and (b)

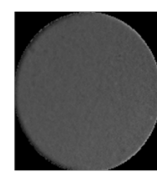

0 cycles

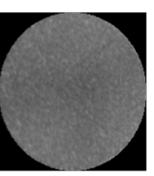

400 cycles

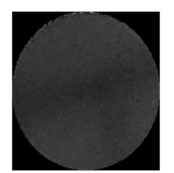

100 cycles

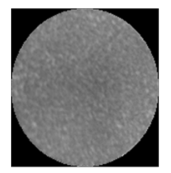

500 cycles

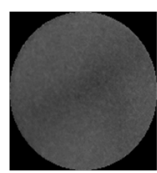

200 cycles

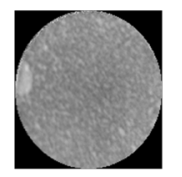

600 cycles

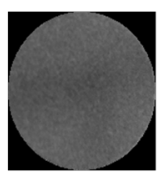

300 cycles

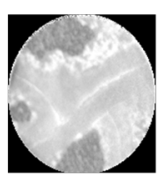

(final TBC failure)
Figure 8.-Furnace test showing progression of delaminations to TBC failure as imaged by upconversion luminescence.

\section{Localized Delamination}

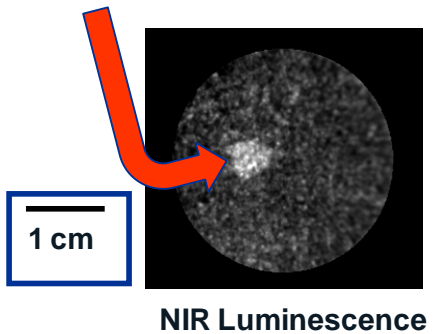

Figure 9.-A small delaminated region is detected on a plasma spray coated disk specimen.

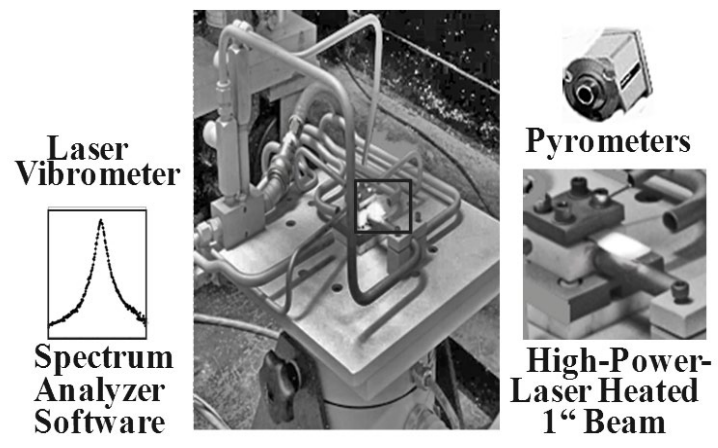

Figure 10.-Laser Heated Cantilever Beam Vibration Test Rig, GRC.

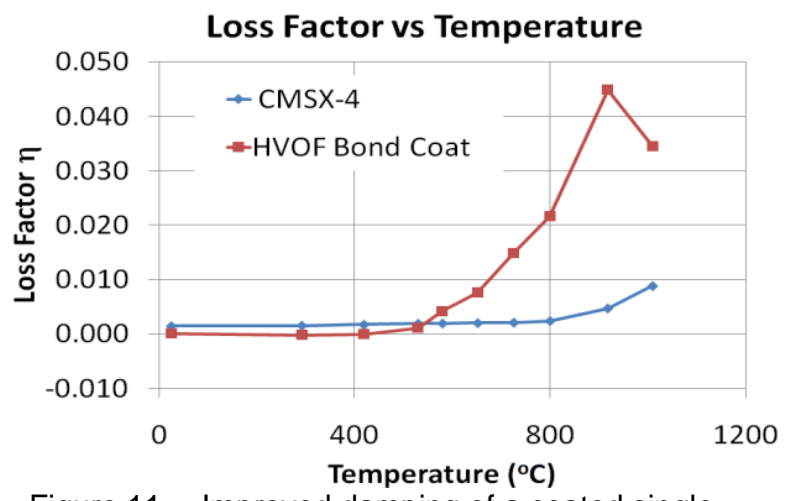

Figure 11.-_Improved damping of a coated single crystal superalloy. 
(SiCNT). While CNT reinforced nanocomposites may be useful for some low temperature uses, the superior temperature and oxidative stability of BNNT make it of interest for engine applications. NASA GRC has a robust capability for producing BNNT (Ref. 28), capable of producing both bulk nanotubes and in-situ coating on substrates. Many substrates have been successfully coated include superalloys, carbon, silicon carbide, silicon, superalloys and various foam structures, an example is shown in Figure 13. As a structural reinforcement within composites, the GRC BNNT has successfully demonstrated improved mechanical properties within glass compositions (Ref. 29) and also recent work within aluminum. Additional applications include thermal management and high temperature electronics.

Silicon Carbide nanotubes (SiCNT) are synthesized by converting the outer wall layers of carbon nanotubes to silicon carbide via a chemical templating procedure (Refs. 30 and 31). Several grams of silicon carbide nanotubes can be synthesized each day. The process generally results in dual layer nanotubes, with an inner core of $\mathrm{C}$ surrounded by an outer layer of $\mathrm{SiC}$, much like a coaxial cable. Samples are 65 to 70 percent $\mathrm{SiC}$ with balance being carbon. Temperature stability of SiCNT, determined by thermogravimetric data in Figure 12(a), shows that weight loss occurs up to $800{ }^{\circ} \mathrm{C}$, as carbon is removed from the sample by oxidation. Slight weight gain occurs above $1000{ }^{\circ} \mathrm{C}$ as oxidation reactions begin to form glassy phases. SiCNTs are being incorporated into environmental barrier coatings (EBC), TBCs and composites.

An NASA NRA with Brown University compliments inhouse experimental work by providing valuable modeling and experimental insight into the mechanical behavior of ceramic nanocomposites. One significant finding which has influenced the direction of in-house work highlighted the strength advantage of multi-wall nanotubes over single wall nanotubes when used as structural reinforcement for composites (Ref. 32).

\section{Lightweight and Multifunctional Engine Structures}

\section{Metal Foams}

Engine and airframe manufacturers alike have made great strides in recent years in weight reduction for both engine and airframe by incorporating new composites and materials. As fan cases and by-pass ducts are large structures relative to other engine components, weight reductions here are an excellent target. One method of weight reduction is to use multifunctional materials. To provide for engine containment, structure must be strong and lightweight, and also capable of containing impact events such as blade out. Various material systems composed of polymer, nanocomposite or metals, could be utilized in sandwich structures. One potentially useful material for lightweight sandwich or other structures may be metal foams. Metal foams, as shown in Figure 14(a),

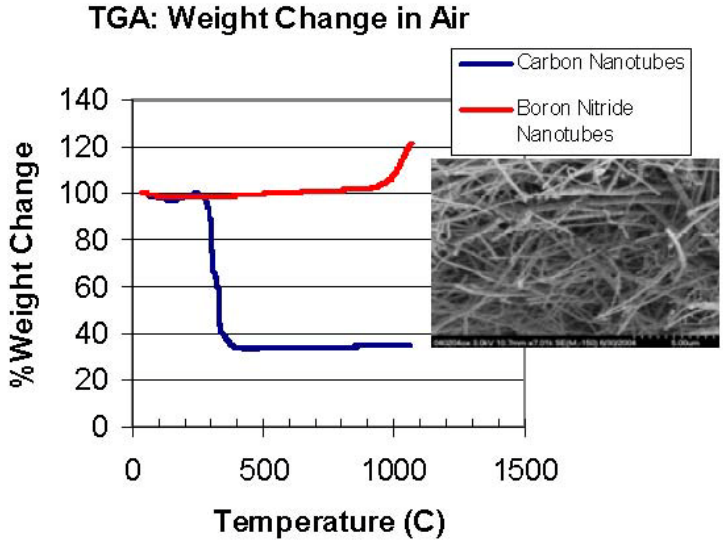

(a)

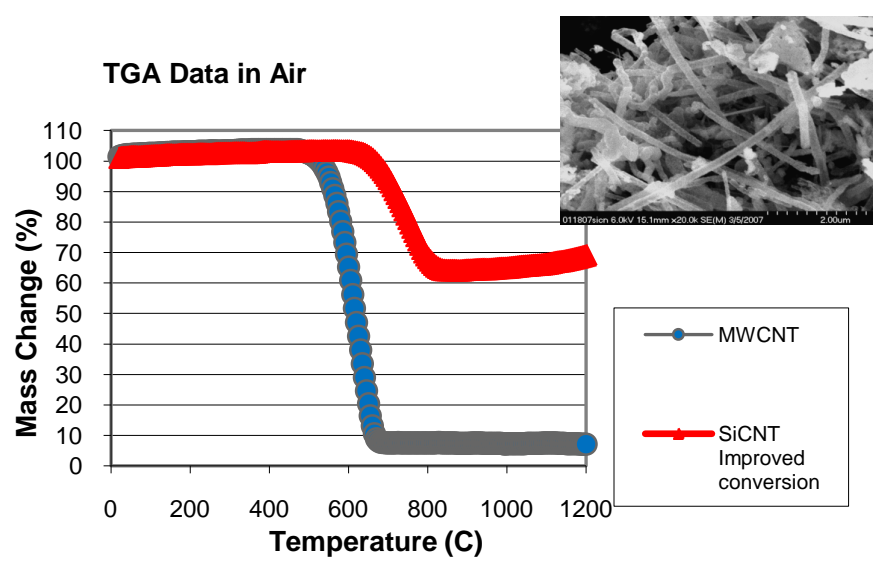

(b)

Figure 12.-(a) Thermogravimetric data demonstrates the thermal stability of BNNT in air at temperature up to $1200^{\circ} \mathrm{C}$. Photo of BNNT following heat treatment in air to $1200^{\circ} \mathrm{C}$. (b) Thermogravimetric data demonstrates the thermal stability SiCNT in air at temperature up to $1200^{\circ} \mathrm{C}$. Photo of SiCNT following heat treatment in air to $1200^{\circ} \mathrm{C}$.

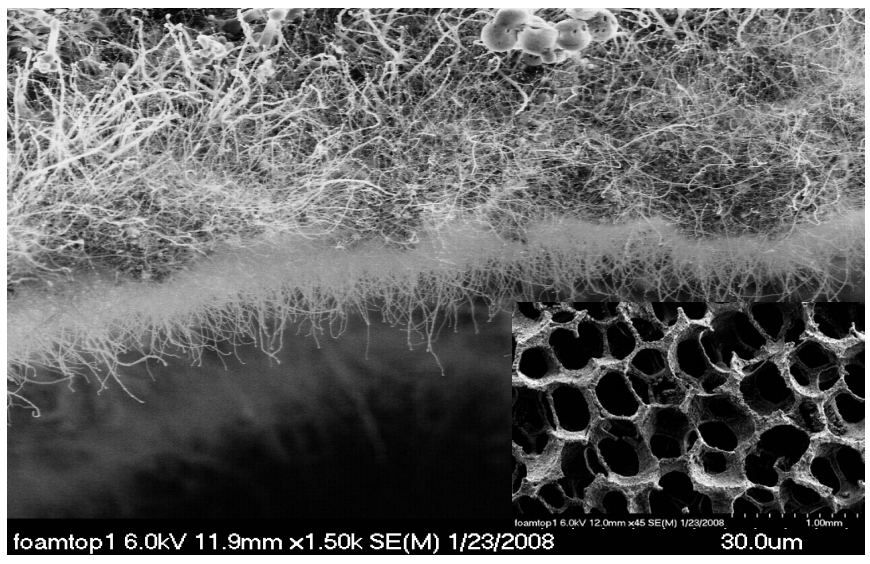

Figure 13.-BNNT deposited on superalloy foam. Inset-coated foam at a lower magnification. 
could supply structural strength and acoustic damping for engine related structures such as the fan case. Polymer foams have already been widely used for impact resistance and sound absorption. Potentially, through the use of metal foams, these functions could be extended into hotter sections of the engine as well. Coupon level testing was carried out on metal foams and demonstrated sound absorption (Ref. 33). Simulated tip rub engine testing with Williams International has also recently been completed (Ref. 33) and demonstrated graceful degradation and minimum tangential loading (Fig. 14(b)).

To understand, model, and eventually optimize foam structures and properties, characterization of non-idealized foams is necessary. A methodology to quantify metal foams based on strut and cell face dimensions has been developed (Ref. 34). Next, understanding of how microstructural features affect pertinent properties needs development.

Many issues with metal foams remain. A serious drawback of this material is weight. Additionally metal foams are not manufactured for the purpose of sound absorption or strength. These attributes along with fatigue tolerance, and density have not been optimized. There are many manufacturers of metal foam so processing approaches and resultant materials vary considerably. Additionally, few high temperature superalloy compositions are available.

\section{Shape Memory Alloys}

Aircraft engines of the future are moving toward real time adaptable systems rather than static engine configurations. These adaptive structures respond to changing performance demands by altering shape, position or geometry as necessary to achieve fuel burn, emission reduction and /or performance benefits. But work performing structures, such as motors, actuators, solenoids, hydraulics and pneumatics, represent additional weight and may therefore negate actual fuel savings from the performance enhancement which they enabled. To avoid this, new solid-state devices may allow adaptive structures for engine applications to also achieve a weight decrease. These actuators would likely be used in devices where traditional hydraulic systems would not be possible. To meet these needs, SFW is developing two types of smart materials, high temperature shape memory alloys (HTSMA), and high temperature adaptive piezoelectric devices.

Shape memory alloys (SMA), with their high energy density, will be useful for large stroke and low frequency applications. There are many potential engine applications starting with simple replacement of conventional actuators, but in addition there are adaptive chevrons (Ref. 35), variable area exhaust nozzles (Ref. 36), acoustic liners, shape changing blades and vanes (Ref. 37), flow control devices, adaptive inlets (Ref. 38), seals, and others. Yet while these applications have been demonstrated, the commercial SMAs or hydraulic systems that were used were only a placeholder for HTSMAs. Currently available SMAs, typically NiTi, are usable to only $70{ }^{\circ} \mathrm{C}$, insufficient for practical situations. SFW has targeted the development of high temperature shape memory alloys (HTSMA) for use to $200{ }^{\circ} \mathrm{C}$. Additional compositions are being developed for much higher temperature applications, up to $500{ }^{\circ} \mathrm{C}$, by the FA Supersonics Project. A HTSMA driven variable area exhaust nozzle demo for a high by-pass ratio engine is a currently unfunded goal within SFW.

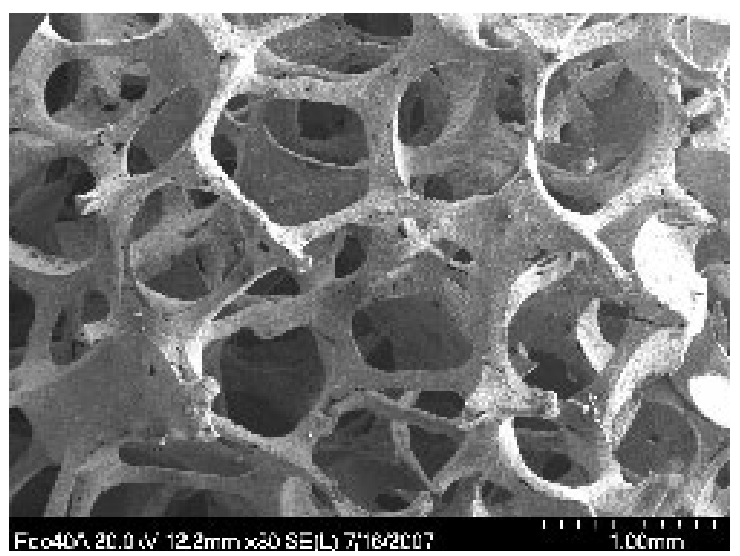

(a)

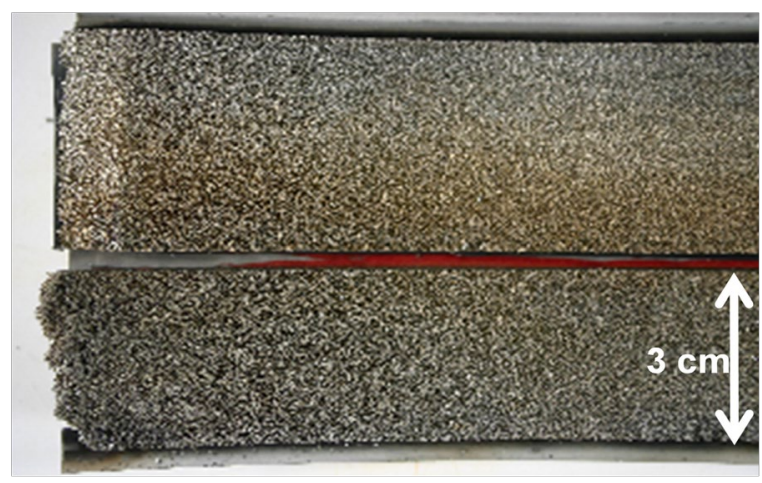

(b)

Figure 14.-(a) Typical metal foam. (b) Post engine tested metal foam arc segments

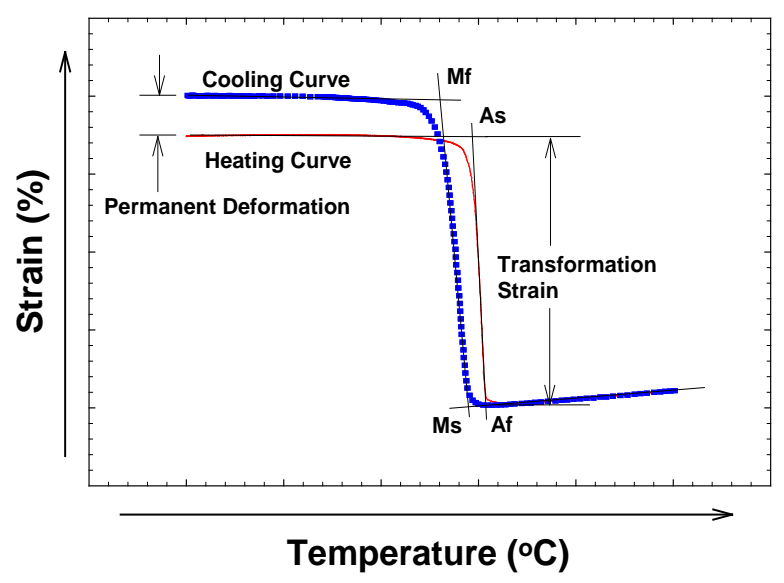

Figure 15.--Idealized behavior of a HTSMA (Ref. 43). 
There are at least four requirements (courtesy Ron Noebe, GRC) for successful HTSMA development for actuators: 1) Martensitic finish temperature (Mf) of at least $80^{\circ} \mathrm{C}$. This is necessary to prevent premature actuation in harsh environments. Commercial SMA materials do not meet this requirement. 2) Dimensional stability during thermal cycling for long-life and durability. This requires little or no irrecoverable strain. 3) Large recoverable transformation strain for large stroke and high work output. 4) Narrow hysteresis for fast actuation. These qualities are shown in the idealized behavior of a HTSMA shown in Figure 15.

Several new NiTiPd-X compositions have been documented (Refs. 39 to 43) to meet most of the above requirements. These compositions are superior to NiTi alloys in both higher transformation temperatures and dimensional stability. On-going research is striving for additional improvements in dimensional stability. The hysteresis behavior of some of the compositions in this family is shown in Figure 16 (Ref. 44).

In another alloy system, NiTiHf, very promising results were also achieved (Ref. 44). This system has been reported to have poor performance with low Mf temperatures, wide hysteresis, poor dimensional stability, poor ductility and difficult processing. However, by incorporating nanodispersion strengthening, alloys with outstanding properties including high Mf temperatures were obtained, shown in Figure 17.

Collaboration with industrial partners as well as other government facilities and universities, is a desired outcome for most efforts within SFW. A clear success story exists in the collaboration within the SMA actuator community. The CASMART organization is comprised of primary and secondary materials producers to end users, along with alloy specialists, and modelers. They come together to advanced SMA technology, developing alloy compositions and processing, developing test standards and alloy certification standards, by creating models and methodologies, and by promoting system-level developments. This group was formed in 2007 by Boeing, GRC, LaRC, and Texas A\&M and has grown to nine members (shown in Fig. 18), each with their own unique role. Additionally, GRC researchers have worked through the NRA process to find productive partnership with researchers and students at the Texas Engineering Experiment Station, Texas A\&M University, who have performed complimentary work in both processing and modeling under a cooperative agreement.

\section{Adaptive Piezoelectric Technology}

While SMAs are appropriate for applications which require large displacements and low frequencies, applications requiring small displacements and high frequencies, may benefit from piezoelectric devices. Piezoelectrics may be appropriate for applications such as active fuel modulation, and active vibration damping. The integrated structural

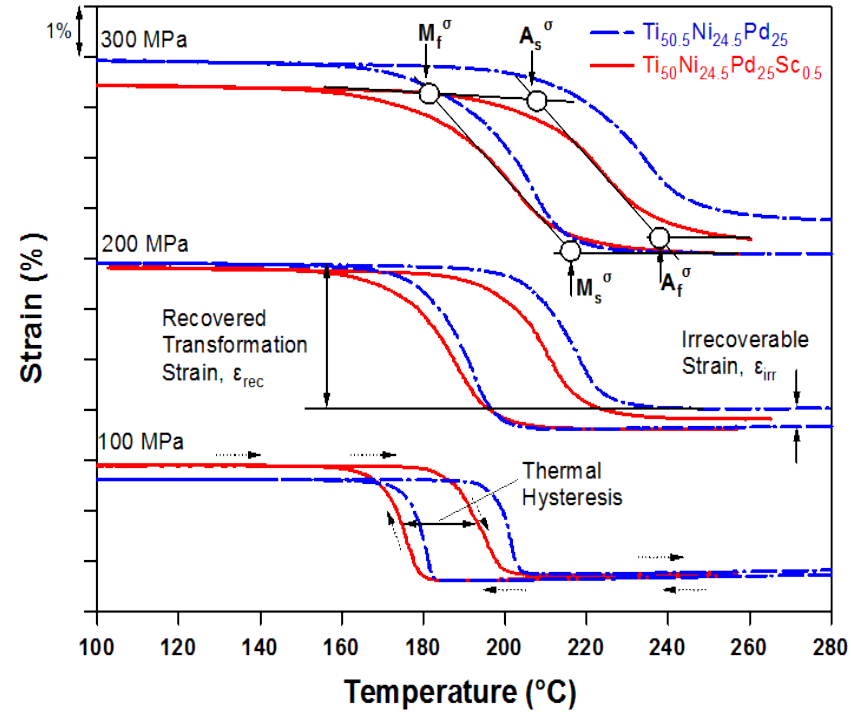

Figure 16.-Hysteresis plots for NiTiPd-X compositions (Ref. 43).

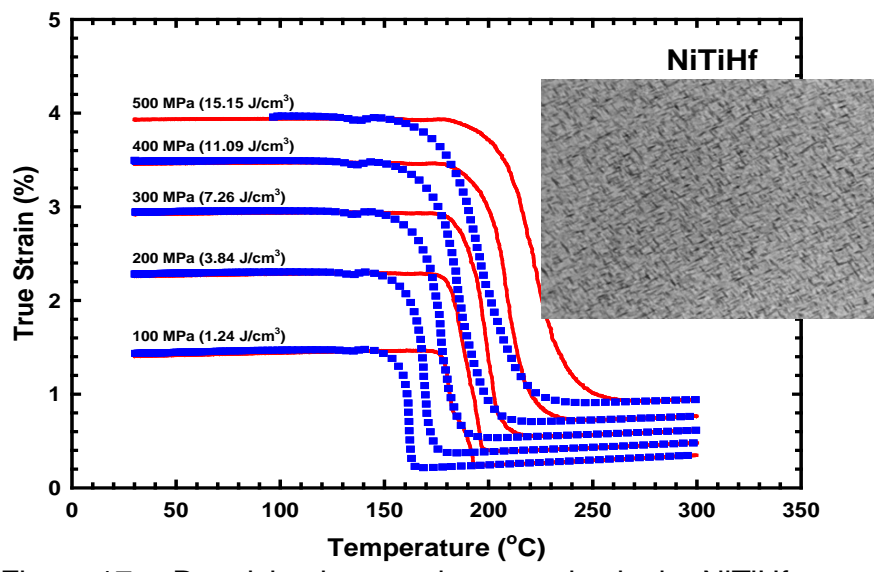

Figure 17.-Promising hysteresis properties in the NiTiHf system. Inset-Microstructure of nanodispersion strengthened NiTiHf alloy.

approach envisioned for an advanced term hybrid wing aircraft utilizing embedded engines will likely require vibration suppression (Ref. 45). An effort to develop high temperature piezo-ceramic compositions exists at GRC, funded by the FA Supersonics Project. Leveraging this effort, SFW is developing the controls and methodology to utilize these new materials. Active damping technology enables the reduction of hazardous vibration and associated dynamic stresses, thereby increasing life of a component. To assure sufficient fatigue life, designers often must increase structure and thereby add weight and volume. As an example problem, the Adaptive Structures team is working to develop shunted piezoelectric damping and/or active control with piezoelectric actuators to reduce fan and compressor blade vibrations. This 
will permit thinner and more highly loaded blades. This will also allow distortion tolerant fan blades for embedded engines which are of interest for $\mathrm{N}+2$ and $\mathrm{N}+3$ concepts where boundary layer ingestion may occur (Ref. 45). More near term, thinner blades will enable reduced fuel burn through weight reduction and reduced noise as well.

Significant resonant stress reduction in flat plates (Refs. 46 and 47) and also on a fan blade was demonstrated with both passive shunt circuits and an active control system (Refs. 47 and 48). A representative result is shown in Figure 19. Testing has also been performed under centrifugal loading to ascertain material and circuit integrity (Ref. 49). The next phase will test embedded piezoelectric devices within scaled composite blades in the Dynamic Spin Rig. Electrical power will be transferred to the rotating blades using wireless telemetry. Preliminary runs employing a lightweight inductive power supply have been promising.

\section{More Electric Propulsion}

Without doubt, the future of aviation will be more electric. While an all-electric commercial aircraft may be considerably in the future, there are other options. An exciting N+3 concept under investigation in SFW is turboelectric distributed propulsion. Also, current civil aviation has increasing electrical demands from instrumentation to passenger laptops. Powering these requirements constitutes a drain on available power from the engine. Solid oxide fuel cells (SOFC) are one method of reducing this demand on engines. Of additional interest for the SFW project is lightweight motors, super capacitors and nanotechnology.

\section{Turboelectric Distributed Propulsion}

Turboelectric distributed propulsion technology is a fundamentally unique approach to potentially meet future propulsion requirements. While this approach can be developed for tube-and-wing configured aircraft, when coupled with a hybrid wing aircraft, significant benefits are expected (Ref. 50). The potential N+3 future aircraft would address every corner of the SFW design space (Fig. 1). Some of these benefits are listed in Figure 20. This concept enables integrated engine and aircraft architectures that are predicted to reduce both drag and fuel burn from the airframe and allow for lower fuel burn and emissions from the propulsion system. This idea relies on power distributed electrically from turbinedriven generators to motors that drive the multiple propulsive fans, see Figure 21. The turboelectric propulsion concept has been addressed in detail elsewhere (Refs. 50 to 52) and was the subject of a recent NASA sponsored workshop (Ref. 51). Representatives from three NASA centers, Air Force, industry and universities were present and took part in developing technology roadmaps. Recent advances in both cryocooler technologies and superconducting materials have generated renewed interest in this approach. The distributed turboelectric propulsion system requires significant weight reduction of cryogenic and superconducting components for this concept to be competitive (Ref. 50) with more conventional approaches. Therefore continued improvements to these technologies are currently pursued within SFW through a combination of SBIRs, contracts and in-house efforts. Recent accomplishments include a preliminary design of a cryocooler which enabled an 80 percent weight reduction while also meeting efficiency goals (Ref. 52). Additionally, in a SBIR effort, an improved low loss MgB2 superconducting wire was developed with fine filaments and a high resistance matrix (Ref. 52). Model developments for motor and generator concepts are currently underway. Also, an in-house high temperature super conducting motor has been constructed and will be soon tested.

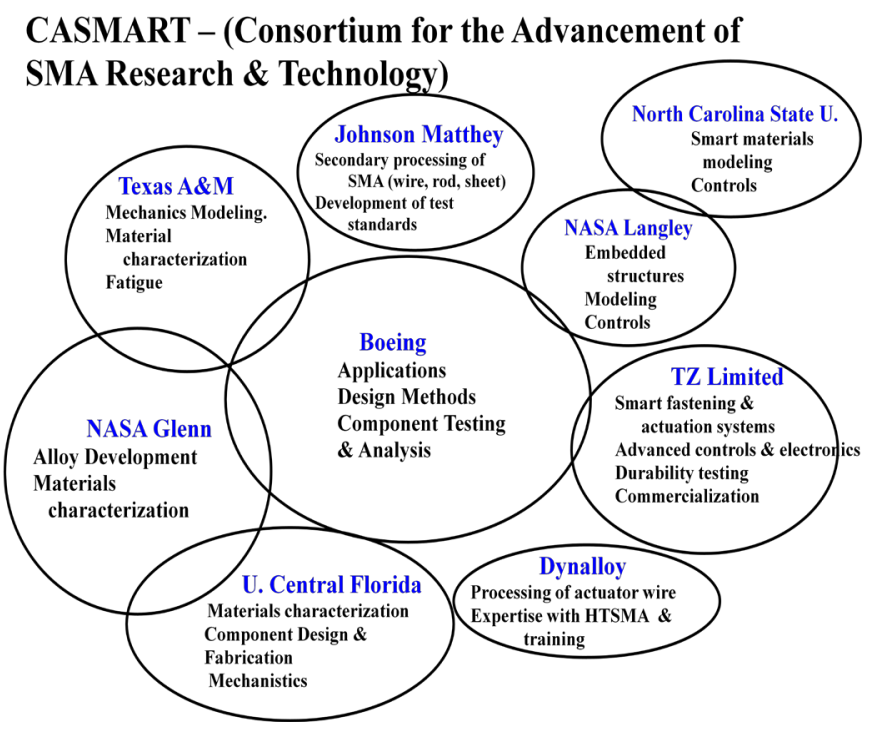

Figure 18.-CASMART organization works to develop SMAs.

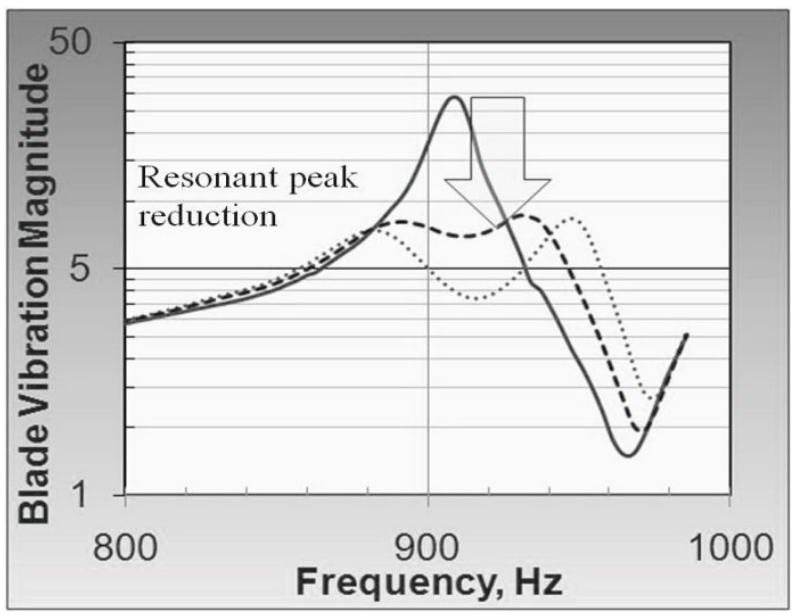

Figure 19._Typical piezoelectric damping. 


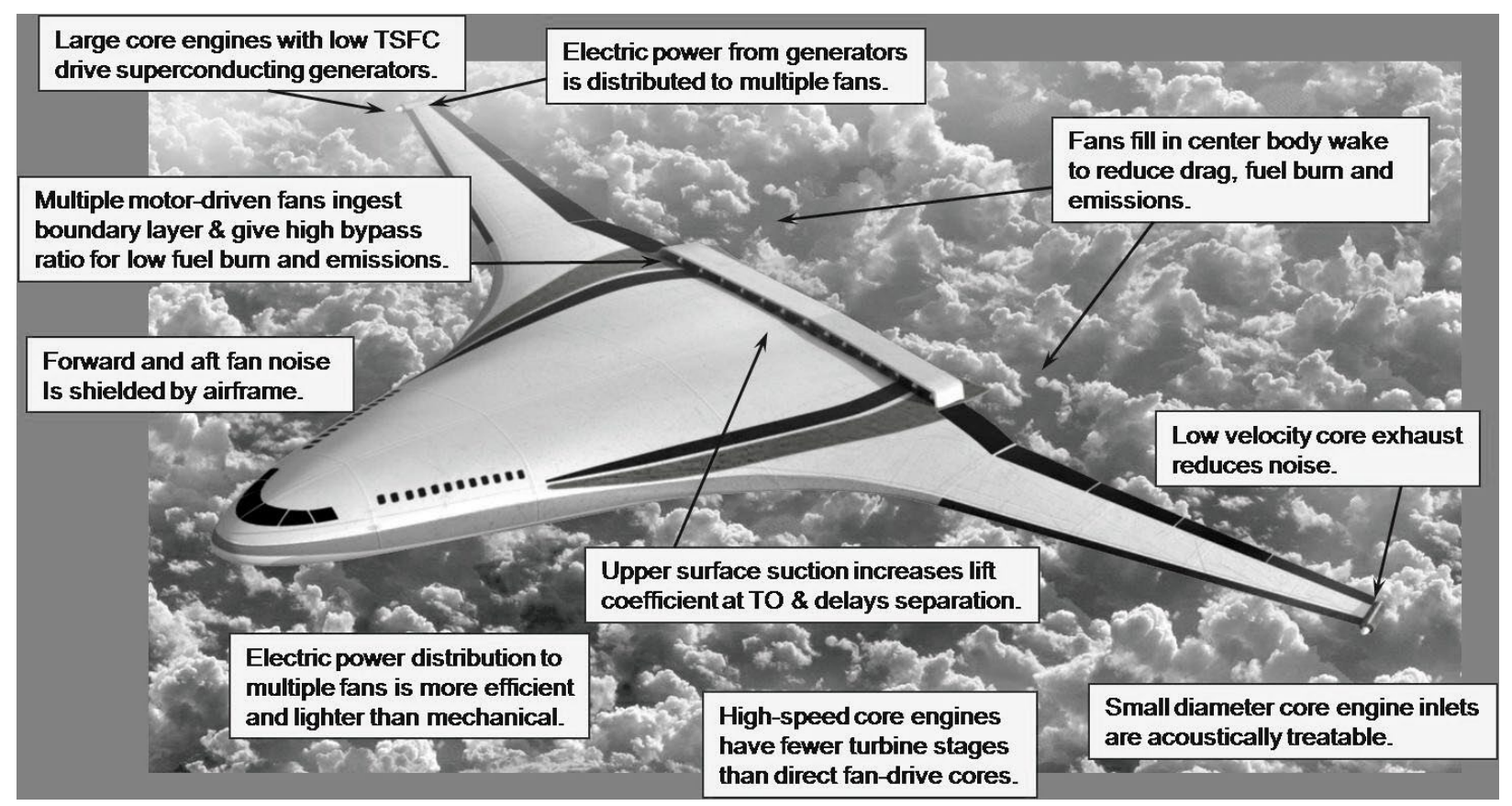

Figure 20.-Multiple benefits may be obtained from the turboelectric propulsion approach.

(Courtesy G. Brown, GRC).

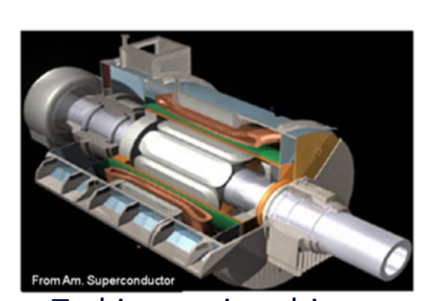

Turbine engine driven superconducting generator
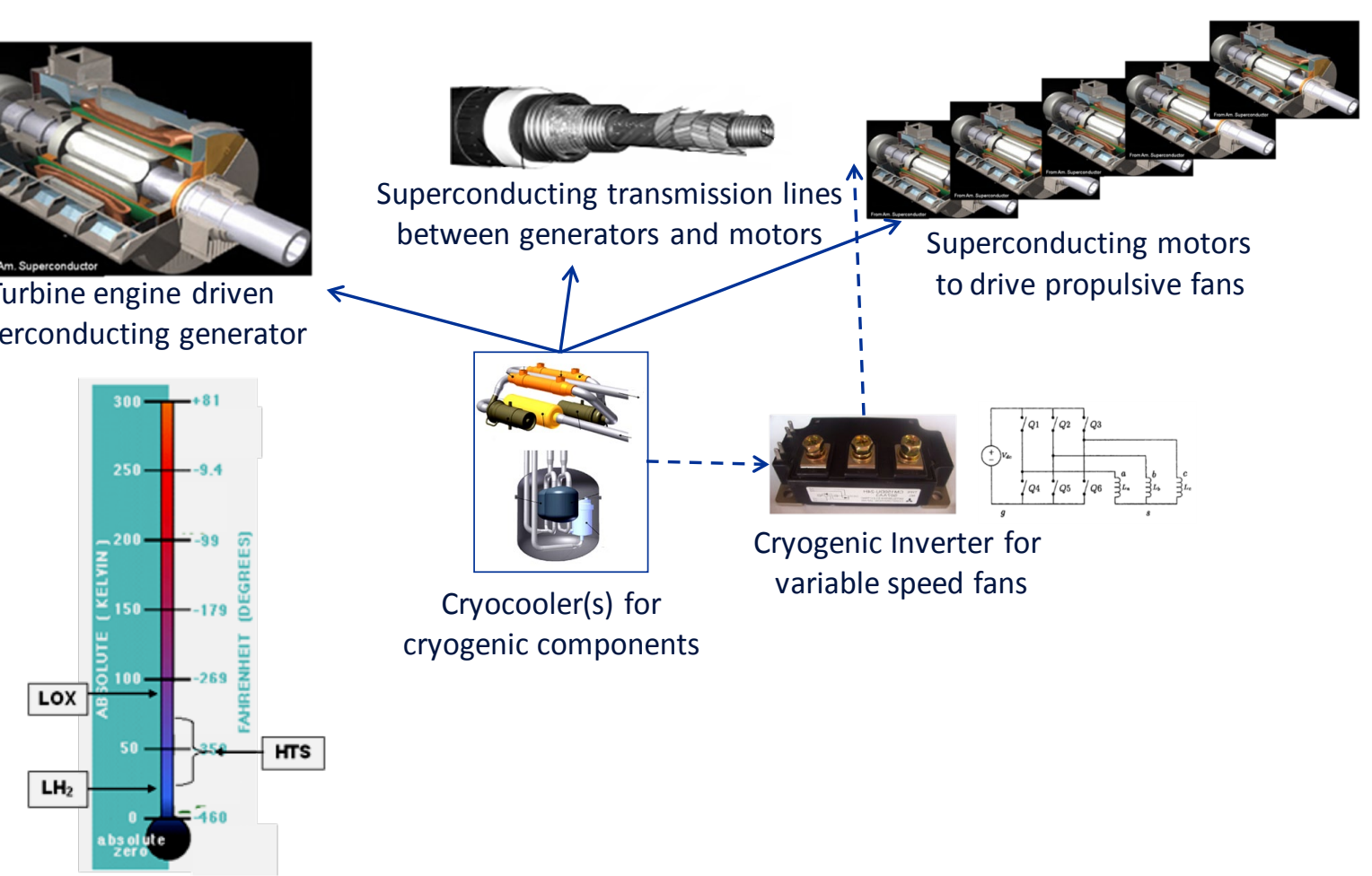

Figure 21.-Components of turboelectric propulsion. (Courtesy G. Brown, GRC). 


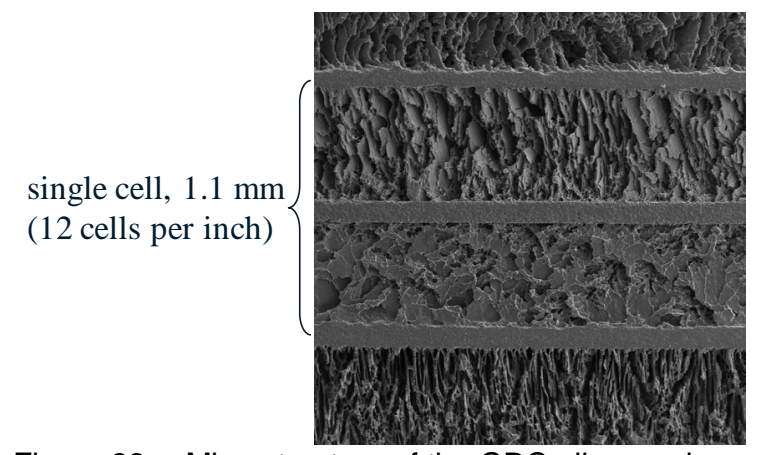

Figure 22.-Microstructure of the GRC all-ceramic SOFC.

\section{Solid Oxide Fuel Cells (SOFC)}

The auxiliary power unit (APU) provides electricity to the plane's on-board systems while in flight and on the ground to provide for passenger convenience and comfort. Generally, APUs are gas-turbine driven generators and are inefficient and polluting. Fuel cell driven APUs would provide significant reduction in fuel burn, NOx and noise while the aircraft is on the ground. But PEM fuel cells do not perform well at high altitudes due to the need to control hydration of the electrolyte. Hybrid PEM/turbine APUs combines fuel cell ground based performance with a gas turbine's high altitude advances (Ref. 53). Potentially, the commercially PEM fuel cells could be replaced with less mature Solid Oxide Fuel Cell (SOFC) technology. Advantages of SOFC fuel cells include better performance at altitude than PEM cells, reduced CO poisoning and better sulfur tolerance. However, SOFCs are heavy and so unsuitable for aviation. SFW has a small effort in SOFC technology with the goal of improved specific power density (power output relative to weight). New SOFC designs at GRC have enabled improved specific power density (power output relative to weight) devices up to $1 \mathrm{~kW} / \mathrm{kg}$ (Ref. 53). The unique microstructure of the GRC SOFC, shown in Figure 22, provides the opportunity for much lighter weight devices while maintaining a robust structure. An additional advantage of this technology is that it does not require expensive precious metals. The all-ceramic design has been successfully tested as a small stack. Future work will test larger stacks and evaluate durability.

\section{Additional Efforts}

Additional work exists at a low level as an informal technology incubator. All are at low TRL. Topics such as nanocomposites, aerogels, thermoelectrics, power harvesting, lightweight motors, oil free bearings and others are explored. As the technology matures, feasibility is continually evaluated. Some of these topics will be elevated in significance, while other technologies will be de-emphasized or dropped. The SFW Materials and Structures portfolio is flexible and as some technologies are found to fall short of the hoped-for impact, rebalancing occurs. As always within the FA Program, research will be supplemented by NRA awards as well as SBIRs

\section{Conclusion}

The Subsonics Fixed Wing Project has the clear objective of addressing environmental challenges for subsonic aircraft and improving their performance through the development of technologies and tools. Advances in materials and structures technologies are essential to meet the SFW goals for reduced fuel consumption, reduced noise and reduced emissions for future generations of aircraft. From new engine concepts operating at higher temperatures with less fuel consumption and pollution, to radically different aircraft propulsion systems, structures and materials advances are the enabler to the future of aviation.

\section{References}

1. http://www.aeronautics.nasa.gov/fap/sfw_research_overview_fe ature.html

2. J. Penner, D. Lister, D. Griggs, D. Dokken, M McFarland, eds. Aviation and the Global Atmosphere: A Special Report of the Intergovernmental Panel on Climate Change. Cambridge, UK: Cambridge University Press, 1999.

3. R. Miller, "Design Approaches for High Temperature Composite Aeroengine Components," Comprehensive Composite Materials, Vol. 6, ISBN: 0-080437249, pp. 181-207, 2000.

4. Proctor, M.P., and Delgado, I.R., "Leakage and Power Loss Test Results for Competing Turbine Engine Seals,” NASA/TM2004-213049, ARL-TR-3157, GT2004-53935, May 2004.

5. Delgado, I.R., and Proctor, M.P., "Continued Investigation of Leakage and Power Loss Test Results for Competing Turbine Engine Seals,” NASA/TM-2006-214420, ARL-MR-0643, AIAA-2006-4754, Sep. 2006.

6. Arora, Gul K., and Proctor, Margaret P., "JTAGG II Brush Seal Test Results,” 33rd AIAA/ASME/SAE/ASEE Joint Propulsion Conference and Exhibit, Seattle, WA, AIAA-97-2632, NASA TM-107448, ARL-TR-1397, Jul. 6-9, 1997.

7. Arora, G.K., Proctor, M.P., Steinetz, B.M., and Delgado, I.R., "Pressure Balanced, Low Hysteresis, Finger Seal Test Results," $35^{\text {th }}$ Joint Propulsion Conference and Exhibit sponsored by AIAA, ASME, SAE, and ASEE, Los Angeles, CA, AIAA-992686, NASA/TM-1999-209191, ARL-MR-457, Jun. 20-24, 1999.

8. Steinetz, B.M., and Hendricks, R.C., "Overview of NASA Glenn Seal Development Program,” NASA/CP-2001211208/VOL1, pp. 1-21, Oct. 2001.

9. Steinetz, B.M., Hendricks, R.C., and Munson, J.H., “Advanced Seal Technology Role in Meeting Next Generation Turbine Engine Goals,” NASA/TM-1998-206961, 1998.

10. Proctor, Margaret P., and Steinetz, Bruce M., "Noncontacting finger seal,” United States Patent No. 6,811,154 B2, Nov. 2004.

11. Delgado, I.R., Proctor, M.P., Steinetz, B.M., Flowers, J., and Oswald, J.J., "An Introduction to NASA's High Temperature, High Speed Turbine Seal Test Facility,” NASA/TM-2006214371, ARL-MR-0645, Jul. 2006. 
12. R. MacKay, et al., "A New Approach of Designing Superalloys for Low Density,” Journal of Metals, Jan. 2010, in press.

13. R. MacKay, et al., "Alloy Design Challenge: Development of Low Density Superalloys for Turbine Blade Applications," NASA/TM-2009-215819.

14. S. Wlodek, M. Kelly, and D. Alden, "The Structure of Rene 88 DT,” Superalloys 1996, pp. 129-136.

15. EPM Materials Program Final Technical Report, Task K - Long Life Compressor/Turbine Disk Material, Contract NAS3-26385, May 2000.

16. J.I. Eldridge, T.J. Bencic, C.M. Spuckler, J. Singh, and D.E. Wolfe, "Delamination-Indicating Thermal Barrier Coatings Using YSZ:Eu Sublayers”, Journal of the American Ceramic Society, Vol. 89, No. 10, pp. 3246-3251 (2006).

17. J.I. Eldridge, C.M. Spuckler, and J.R. Markham, "Determination of Scattering and Absorption Coefficients for Plasma-Sprayed Yttria-Stabilized Zirconia Thermal Barrier Coatings at Elevated Temperatures,” Journal of the American Ceramic Society, vol. 92, no. 10, pp. 2276-2285 (2009).

18. J.I. Eldridge, R.E. Martin, and D.E. Wolfe, "Monitoring Delamination of Thermal Barrier Coatings During Interrupted Furnace Cycling by Near-Infrared and Upconversion Luminescence Imaging,” presented at the 33rd International Conference on Advanced Ceramics \& Composites, Daytona Beach, FL, Jan. 18-23, 2009.

19. P. Crowther, "Non Destructive Evaluation of Coatings for Land Based Gas Turbines Using a Multi-Frequency Eddy Current Technique,” Insight Nondestruct. Test Cond. Monit., 46 [9] 547-49 (2004).

20. N.W. Wu, K. Ogawa, M. Chyu, and S.X. Mao, "Failure Detection of Thermal Barrier Coatings Using Impedance Spectroscopy,” Thin Solid Films, 457, 301-306 (2004).

21. U. Schulz, W.A. Kaysser, M. Sips, and P. Kaul, "Impedance Spectroscopy of Thermal Barrier Coatings as Non-Destructive Evaluation Tool for Failure Detection,” Z. Metallkd., 96 [7], 725-30 (2005).

22. G. Neewaz and X. Chen, "Progressive Damage Assessment in Thermal Barrier Coatings Using Thermal Wave Imaging Technique,” Surf. Coat. Technol., 190, 7-14 (2005).

23. B. Franke, Y.H. Sohn, X. Chen, J.R. Price, and Z. Mutasim, "Monitoring Damage Evolution in Thermal Barrier Coatings with Thermal Wave Imaging,” Surf. Coat. Technol., 200, 129297 (2005).

24. X. Peng and D.R. Clarke, "Piezospectroscopic Analysis of Interface Debonding in Thermal Barrier Coatings," J. Am. Ceram. Soc., 83[5], 1165-70 (2000).

25. J.I. Eldridge, T.J. Bencic, S.W. Allison, and D.L. Beshears, "Depth-Penetrating Temperature Measurements of Thermal Barrier Coatings Incorporating Thermographic Phosphors,” J. Thermal Spray Technol., 13[1], 44-50 (2004).

26. J.I. Eldridge, "Optical Diagnostics for High-Temperature Thermal Barrier Coatings,” J.I. Eldridge, invited talk at the 2009 Fundament Aeronautic Program Annual Review, Atlanta, GA , Sep. 29-Oct. 1, 2009.

27. D. Zhu, R.A. Miller, K.P. Duffy, and L. Ghosn, "High Temperature Damping Behavior of Plasma Sprayed Thermal Barrier and Protective Coatings", Advanced Ceramic Coatings for Structural, Environmental, and Functional Applications Symposium, 33rd International Conference \& Expo on Advanced Ceramics \& Composites, Jan. 18-23, 2009 Daytona Beach FL; NASA/TM-2009-215671, in press.
28. J. Hurst, D. Hull, and D. Gorican "Synthesis of Boron Nitride Nanotubes for Engineering Applications”, Ceramic Engineering and Science Proceedings, Vol. 26, Issue 8, 2005.

29. N. Bansal, J. Hurst, and S. Choi, "Boron Nitride NanotubesReinforced Glass Composites”, J. Am. Ceram. Soc., 89 [1] 388390 (2006)

30. J. Hurst, "Synthesis of Silicon Carbide Nanotubes", 2007 NanoMaterials for Defense Applications Symposium.

31. T. Taguchi, N. Igawa, and H. Yamamoto, "Synthesis of Silicon Carbide Nanotubes”, J. Am. Ceram. Soc. 88 [2] 459-461 (2005).

32. W. Curtin, H. Xia, and B. Sheldon, "Physics-Based Multiscale Modeling of Multifunctional Nanoceramic Composites for Subsonic Engine Components, Year 2 Progress Report.” NNX07AO07A.

33. C.L. Bowman and M.G. Jones, "Simulated Tip Rub Testing of Low-Density Metal Foam,” NASA/TM-2009-215818, 2009.

34. S. Raj, to be published

35. T.L. Turner, R.D. Buehrle, R.J. Cano, and G.A. Fleming, "Design, Fabrication, and Testing of SMA Enabled Adaptive Chevrons for Jet Noise Reduction,” SPIE Proc. Vol. 5390 (2004).

36. N.M. Rey, G. Tillman, R.M. Miller, T. Wynosky, M.J. Larkin, J.D. Flamm, and L.S. Bangert, "Shape Memory Alloy Actuation for a Variable Area Fan Nozzle,” SPIE Proc. Vol. 4332 (2001) pp. 371-382.

37. M.A. Qidwai, A. Bhattacharya, I. Vahhi, and S. Pulnev, "Initial Investigation in Actuator Design Using High temperature Shape Memory Alloy,” SPIE Proc. Vol. 5053 (2003) pp. 81-91.

38. D.M. Pitt, J.P. Dunne, E.V. White and E. Garcia, "SAMPSON Smart Inlet SMA Powered Adaptive Lip Design and Static Test,” AIAA Paper No. 01-1359

39. G.S. Bigelow, D.J. Gaydosh, A. Garg, S.A. Padula, and R.D. Noebe, "Effects of Stoichiometry on Transformation Temperatures and Actuator-Type Performance of NiTiPd and NiTiPdX High-Temperature Shape Memory Alloys,” SMST 2007: Proceedings of the International Conference on Shape Memory and Superelastic Technologies, ASM International, Metals Park, OH., (2008), pp. 83-92.

40. G. Bigelow, R. Noebe, S. Padula, and A. Garg, "Development and Characterization of Improved High Temperature Shape Memory Alloys by Solid Solution Strengthening and Thermomechanical Processing of NiTiPd Alloys,” SMST 2006: Proceedings of the International Conference on Shape Memory and Superelastic Technologies, ASM International, Metals Park, OH., (2008), pp. 113-132.

41. A. Stebner, S.A. Padula, R.D. Noebe, D.D. Quinn, "Development, Characterization, and Design Considerations of $\mathrm{Ni}_{19.5} \mathrm{Ti}_{50.5} \mathrm{Pd}_{25} \mathrm{Pt}_{5}$ High-Temperature Shape Memory Alloy Helical Actuators," J. of Intelligent Material Systems and Structures, Vol. 20, Issue 17, 2009.

42. J. Ma, I. Karaman, and Ronald D. Noebe, "High Temperature Shape Memory Alloys,” submitted International Materials Review, (2010).

43. K.C. Atli, I. Karaman, R.D. Noebe, A. Garg, Y.I. Chumlyakov, and I.V. Kireeva, "Improvement in the Shape Memory Response of $\mathrm{Ti}_{50.5} \mathrm{Ni}_{24.5} \mathrm{Pd}_{25}$ High Temperature Shape Memory Alloy with Scandium Microalloying,” accepted Metallurgical \& Materials Transactions (2010).

44. I. Karaman and D.C. Lagoudas, "Thermo-Mechanical Processing and Modeling of High Temperature Shape Memory 
Alloys for Multifunctional Engine Components,” Second Annual Progress Report, Texas Engineering Experiment Station, Texas A\&M University, Cooperative Agreement NNX07AB56A, Dec. 31, 2008.

45. M. Tong, S. Jones, W. Haller, R. Handschuh, "Engine Conceptual Design Studies for a Hybrid Wing Body Aircraft”, NASA TM-2009-215680.

46. P-SAR '09 - "A Multi-Mode Blade Damping Control Using Shunted Piezoelectric Transducers with Active Feedback Structure"

47. Kirsten Duffy, Andy Provenza, Jeff Trudell, and James Min, "Passively Shunted Piezoelectric Damping of Centrifugally Loaded Plates" 50th AIAA/ASME/ASCE/AHS/ASC Structures, Structural Dynamics, and Materials Conference AIAA-20092524, 17th AIAA/ASME/AHS Adaptive Structures Conference, May 4-7, 2009, Palm Springs, CA.

48. James Min, Kirsten Duffy, Jeff Trudell, Ben Choi, Carlos Morrison, Ralph Jansen, and Andy Provenza "A Resonant Damping Study Using Piezoelectric Materials” 49th AIAA/
ASME/ASCE/AHS/ASC Structures, Structural Dynamics, and Materials Conference, 16th AIAA/ASME/AHS Adaptive Structures Conference, Apr. 7-10, 2008, Schaumburg, IL.

49. Ben Choi, Carlos Morrison, James Min, A Multi-Mode Blade Damping Control Using Shunted Piezoelectric Transducers (PE) with Active Feedback Structure," Propulsion-Safety and Affordable Readiness (P-SAR) Review Conference, Mar. 1820, 2009, Myrtle Beach, SC

50. Felder, Kim \& Brown "Turboelectric Distributed Propulsion Engine Cycle Analysis for Hybrid-Wing-Body Aircraft", AIAA-2009-1132, 47 ${ }^{\text {th }}$ AIAA Aerospace Sciences Mtg., Orlando, FL, Jan 7, 2009.

51. NASA Workshop, OAI, Cleveland OH, Feb. 10-11, 2009.

52. Brown, Kim and Felder, "Materials Aspects of Turboelectric Aircraft Propulsion,” Fundamental Aeronautics Annual Meeting, Sep. 29-Oct. 1, 2009.

53. T. Cable and S. Sofie, "A symmetrical, planar SOFC design for NASA's high specific Power Density Requirements,” J. Power Source, Vol. 174, Issue 1, pp. 221-227, 2007. 


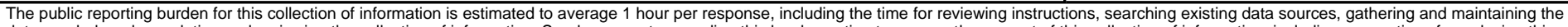

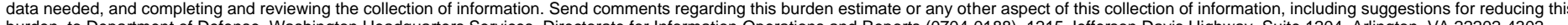

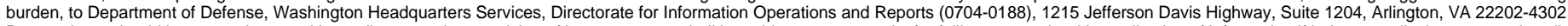

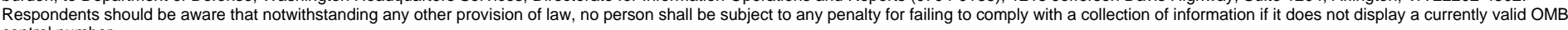

control number.
PLEASE DO NOT RETURN YOUR FORM TO THE ABOVE ADDRESS

\begin{tabular}{l|l|l}
\hline $\begin{array}{l}\text { 1. REPORT DATE (DD-MM-YYYY) } \\
01-09-2011\end{array}$ & $\begin{array}{l}\text { 2. REPORT TYPE } \\
\text { Technical Memorandum }\end{array}$ & 3. DATES COVERED (FrOm - To) \\
\hline
\end{tabular}

\section{TITLE AND SUBTITLE}

Materials and Structures Research for Gas Turbine Applications Within the NASA Subsonic

Fixed Wing Project

5a. CONTRACT NUMBER

5b. GRANT NUMBER

5c. PROGRAM ELEMENT NUMBER

5d. PROJECT NUMBER

6. AUTHOR(S)

Hurst, Janet 5e. TASK NUMBER

5f. WORK UNIT NUMBER

WBS 561581.02.08.15.10

7. PERFORMING ORGANIZATION NAME(S) AND ADDRESS(ES)

National Aeronautics and Space Administration

John H. Glenn Research Center at Lewis Field

Cleveland, Ohio 44135-3191

\section{SPONSORING/MONITORING AGENCY NAME(S) AND ADDRESS(ES)}

National Aeronautics and Space Administration

Washington, DC 20546-0001
8. PERFORMING ORGANIZATION REPORT NUMBER

E-17324

\section{DISTRIBUTIONIAVAILABILITY STATEMENT}

Unclassified-Unlimited

Subject Categories: 01 and 27

Available electronically at http://www.sti.nasa.gov

This publication is available from the NASA Center for AeroSpace Information, 443-757-5802

\section{SUPPLEMENTARY NOTES}

\section{ABSTRACT}

A brief overview is presented of the current materials and structures research geared toward propulsion applications for NASA's Subsonic Fixed Wing Project one of four projects within the Fundamental Aeronautics Program of the NASA Aeronautics Research Mission Directorate. The Subsonic Fixed Wing (SFW) Project has selected challenging goals which anticipate an increasing emphasis on aviation's impact upon the global issue of environmental responsibility. These goals are greatly reduced noise, reduced emissions and reduced fuel consumption and address 25 to 30 years of technology development. Successful implementation of these demanding goals will require development of new materials and structural approaches within gas turbine propulsion technology. The Materials and Structures discipline, within the SFW project, comprise cross-cutting technologies ranging from basic investigations to component validation in laboratory environments. Material advances are teamed with innovative designs in a multidisciplinary approach with the resulting technology advances directed to promote the goals of reduced noise and emissions along with improved performance.

15. SUBJECT TERMS

Materials

\begin{tabular}{|c|c|c|c|c|}
\hline \multicolumn{3}{|c|}{ 16. SECURITY CLASSIFICATION OF: } & \multirow{2}{*}{$\begin{array}{l}\text { 17. LIMITATION OF } \\
\text { ABSTRACT } \\
\text { UU }\end{array}$} & \multirow{2}{*}{$\begin{array}{l}\text { 18. NUMBER } \\
\text { OF } \\
\text { PAGES } \\
19\end{array}$} \\
\hline $\begin{array}{l}\text { a. REPORT } \\
U\end{array}$ & $\begin{array}{l}\text { b. ABSTRACT } \\
U\end{array}$ & $\begin{array}{l}\text { c. THIS } \\
\text { PAGE } \\
\text { U }\end{array}$ & & \\
\hline
\end{tabular}

\section{SPONSORING/MONITOR'S \\ NASA}

11. SPONSORING/MONITORING

REPORT NUMBER

NASA/TM-2011-216747 

